\title{
Breeding for milk and beef in cattle - designing an overall strategy
}

\author{
VEIJO VILVA and U. B. LINDSTRÖM \\ University of Helsinki, Department of Animal Breeding, 00710 Helsinki 71
}

\begin{abstract}
A three-stage selection programme of dual purpose bulls was studied in order to assess the significance of the selection stages and the genetic gain to be expected. In accordance with previous studies the results showed that over $90 \%$ of the economic gain comes from the milk traits. In addition the study showed that over $10 \%$ of the gain is due to the increased feed conversion efficiency, mainly in milk production. The beef performance test of young bulls accounted for only $1-2 \%$ of the total economic gain. Therefore the test stations set up for this purpose might be more efficiently utilised by concentrating on measurement of feed conversion. The study also indicated that direct selection for feed efficiency in milk production would give appreciably higher gain even if it were done on the basis of only 5 daughters/ bull. In practice this might be accomplished by measuring the feed consumption of a limited number of daughters per young bull, 4-5 months after calving for about one month or by collecting 200-300 individual mid-lactational feed consumption records for daughters of young bulls.
\end{abstract}

\section{Introduction}

In a previous study (LINDSTRÖM \& VILVA, 1977) we concluded that our present "dual purpose" breeding policy should be re-evaluated as there economically seemed to be little justification for much culling of bulls on the basis of beef performance test. In accordance with (CUNNINGHAM \& McCLINTOCK 1974, McCLINTOCK \& CUNNINGHAM 1974) our results showed that the optimal programme in breeding for both milk and beef production requires the maximum possible amount of beef crossings on dairy cows. We showed that even in small dairy herds some beef crossing could be done profitably. Our previous paper considered genotype of only two traits, milk yield and growth rate. The results indicated that improvement of milk yield accounted for 90 to $95 \%$ of the gain in aggregate genotype. Feed conversion was considered only indirectly on the beef side, assuming a regression of 3 Scand. fu/ $\mathrm{kg}$ per $\mathrm{kg}$ extra live weight gain. Here our purpose is to extend our results and consider selection for milk yield, growth rate and feed conversion (in both milk and beef production phases) in a three stage selection process. 


\section{Material and methods}

As $65-75 \%$ of the genetic progress in AI programmes is realised through sire selection (SKJERVOLD 1967), this study was limited to selection of young sires. Three stages of selection are possible.

1) selection of young bulls on the basis of an pedigree index including sire's, dam's and maternal grandsire's breeding value for milk yield.

2) selection of bulls at one year of age on the basis of an index including the beef performance test and feed consumption as well as their pedigree index for milk yield.

3) selection of bulls for AI use on a progeny test for milk production of their daughters.

The covariances used in the index equations at stages 2 and 3 were adjusted for the selection at the preceding stages using the following formula (CUNNINGHAM 1975):

$$
\delta_{j k}=\delta_{j k}-\delta_{i j} \delta_{i k} \delta_{i i}^{-1} s
$$

where

$\delta_{j \mathrm{k}}=$ the covariance between variates (or traits) $\mathrm{j}$ and $\mathrm{k}$

$\delta_{i j}=$ the covariance between the index and variate $\mathrm{j}$

$\delta_{\mathrm{ik}}=$ the covariance between the index and variate $\mathrm{k}$

$\delta_{\mathrm{ii}}=$ the variance of the index

$s \quad=\mathrm{i}(\mathrm{i}-\mathrm{t})$, where $\mathrm{i}=$ the selection differential at truncation point $\mathrm{t}$

The economic weights of the dairy and beef traits were multiplied by the corresponding numbers of standard discounted expressions of a dual purpose bull's breeding value obtained by the discounted gene flow method (McCLIN-

Table 1. Basic parameters used (set 1).

Number of daughters per bull sire and matern.

grandsire: 200

Number of lactations per bull dam: 5 ; repeatability: 0.4

Number of daughters per young bull at stage 3: 50

Average number of lactations per cow: 3.5

Survival rate of calves: 0.85

Proportion of beef crossings: 0.3

Test station capacity: 200 bulls/year

Discount rate: 0.03 (SMITH 1978)

\begin{tabular}{|c|c|c|c|c|c|c|}
\hline \multirow{2}{*}{ Trait } & \multirow{2}{*}{$h^{2}$} & \multirow{2}{*}{ s.d. } & \multirow{2}{*}{$\begin{array}{l}\text { Net value } \\
\text { Fmk/unit }\end{array}$} & \multicolumn{3}{|c|}{ Genetic correlation $\left(r_{G}\right)$ with } \\
\hline & & & & $\mathrm{F}_{\mathrm{c}}$ & B & $\mathrm{B}_{\mathrm{c}}$ \\
\hline Milk (M), kg & .2 & 750 & 1.20 & -.6 & .2 & -.2 \\
\hline $\begin{array}{l}\text { Feed. consumpt. } \\
\text { milk prod. }(\mathrm{Fc}) \text { feed units }\end{array}$ & .3 & 200 & -.75 & & -.2 & .3 \\
\hline Beef prod. (B), kg & .5 & 39 & 3.60 & & & -.6 \\
\hline $\begin{array}{l}\text { Feed consumpt. } \\
\text { beef prod }(B c) \text { feed units }\end{array}$ & .4 & 100 & -.75 & & & \\
\hline
\end{tabular}


TOCK \& CUNNINGHAM 1974) considering 5 generations and 12 years ahead. Basically for each trait this method sums the numbers of producing descendants in each year - generation class considered, multiplied by their additive genetic relationship to the bull and by their probability of occurrence. These are then discounted back to the base year.

The economic gains thus indicate the genetic gain in the population per dual purpose insemination. The main parameters used are given in table 1 and represent values pertinent to the Finnish Ayrshire population (BOA 1982, LINDSTRÖM \& VILVA 1977) or were taken from the literature (BECHANDERSEN 1977, DICKINSON et al. 1969, FREEMAN 1967, HOOVEN et al. 1968). Some of the parameters were varied to get an idea of the effect of changes in the various factors: in breeding policy (sets $2 \& 3$ ), economic factors (sets $4 \& 5$ ), different levels of genetic correlations (sets $6 \& 7$ ). A stage 3 selection based on an index of progeny test for both milk yield and feed conversion in milk production (set 8) was also considered.

\section{Results and discussion}

Table 2. shows the results obtained using the base set of parameters. In accordance with our previous results the milk traits account for the major part, $86 \%$, of the overall genetic gain. The main reasons for this are the low price relation between beef net value / dairy net value and the higher accuracy of estimates of breeding values for milk. The extra improvement achieved by selection at stage 2 is thus quite low. It contributes only one percent, and even here a significant proportion of gain comes from correlated responses in milk yield. The selection at stages 1 and 3 results in about $83 \%$ of the gain in beef traits, due to the assumed genetic correlation (of $+0,2$ ) between milk and beef traits and the intensive selection at these stages. The main purpose of stage 2 can thus be considered to be the culling of inferior bulls before AI use.

Table 2. Results of three-stage selection using parameters of Table 1.

$\mathrm{M}_{\mathrm{c}}=$ Feed consumption, Milk

$\mathrm{B}_{c}=$ Feed consumption, Beef

\begin{tabular}{|c|c|c|c|c|c|c|c|c|c|}
\hline \multirow[t]{2}{*}{ Stage } & \multirow[t]{2}{*}{ Selection } & \multirow{2}{*}{$\begin{array}{l}\text { Gain } \\
\text { Fmk }\end{array}$} & \multicolumn{4}{|c|}{ Percentages of gain } & \multicolumn{3}{|c|}{ Value of variates" } \\
\hline & & & Milk & $\mathrm{M}_{\mathrm{e}}$ & Beef & $\mathrm{B}_{\mathrm{c}}$ & 1 & 2 & 3 \\
\hline 1 & .05 & 580 & 86.54 & 10.60 & 1.92 & 0.94 & 41.33 & 9.46 & 3.46 \\
\hline 2 & .70 & 21 & 32.70 & 14.19 & 36.66 & 16.45 & 25.56 & 15.92 & \\
\hline \multirow[t]{2}{*}{3} & .10 & 1354 & 86.71 & 10.59 & 1.81 & 0.89 & & & \\
\hline & Total & 1956 & 86.08 & 10.63 & 2.22 & 1.07 & & & \\
\hline
\end{tabular}

* Loss in accuracy if variate deleted

Variates: stage 1: sire's prog. test, dam's avg. milk yield, mat. grand sires's prog. test stage 2: bull's beef perf. test, feed consumption stage 3: bull's own prog. test 
Although proportionately low, the economic gain from stage 2 is, however, quite substantial in absolute monetary terms at the population level and exceeds at least 10 -fold the costs involved.

The gain in feed conversion efficiency accounts for almost $12 \%$ of the total gain. Most of this gain comes through indirect selection on milk yield. As this figure is based on a rather conservative estimate of the correlations involved, it probably gives a fair idea of the minimum gain to be expected. At present there are no reliable estimates of the association between feed efficiency in beef performance testing $(\mathrm{Bc})$ and feed efficiency in milk production (Mc). It can be argued that, as the feed consumption for maintenance in both production forms is a common characteristic, the genetic correlation between $\mathrm{Bc}$ and $\mathrm{Mc}$ should be fairly high. In our view the production of beef protein in rapidly growing bulls is a metabolic process differing to a considerable extent from the production of milk protein in adult females. Therefore, the genetic correlation need not necessarily be very close. Likewise, is it probable that in spite of the low correlation between growth rate and milk production generally noted (FRIEDEL \& RYBKA 1980, LINDSTRÖM 1974) the association of feed conversion in the two production forms should be high? Studies designed to reveal the magnitude of this association are needed.

\section{Varying parameters}

Table 3. gives the results of varying the parameter values. Reducing the proportion of matings by beef sires to zero (set 2) or using a much higher discount rate (set 5) both reduce the economic gains considerably. However, the main result is the relative insensitivity of the proportions of the gains from different sources to the changes in the parameters. Doubling the price of beef (set 4) more then doubles the contribution of beef to the total gain, but it still remains low. If the genetic correlation between milk and beef traits is zero (set 7), over $99 \%$ of the total gain is accounted for by the milk traits. A higher overall level of genetic correlation (set 6) results in an increased importance of feed conversion efficiency. The inclusion into the stage 3 index of a progeny test on the feed conversion efficiency in milk production based only on 5 daughters (set 8 ) increases the overall economic gain by almost 6 $\%$.

Our results clearly indicate the major emphasis to be put on genetic improvement of milk production in a scheme utilising dual purpose cows. The relatively small economic contribution of the beef performance test of bulls indicates that the test stations set up for this purpose might be more efficiently utilised by concentrating on measurement of feed conversion of bulls' daughters for milk production. This is in accordance with SKJERVOLD (1977). 
Table 3. Results of three-stage selection using different sets of parameters

\begin{tabular}{lccccccccr}
\hline \multirow{2}{*}{ Set } & \multicolumn{3}{c}{ Percentage of total gain at } & \multicolumn{3}{c}{ Percentage of gain } & \multicolumn{2}{c}{ Total gain } \\
\cline { 2 - 9 } & stage 1 & stage 2 & stage 3 & Milk & M $_{c}$ & Beef & $B_{c}$ & Fmk & Relative \\
\hline 1 & 29.67 & 1.08 & 69.25 & 86.08 & 10.63 & 2.22 & 1.07 & 1956 & 100.0 \\
2 & 29.63 & 1.27 & 69.10 & 85.09 & 10.51 & 2.97 & 1.43 & 1385 & 70.8 \\
3 & 29.53 & 2.09 & 68.38 & 85.58 & 10.66 & 2.54 & 1.22 & 1965 & 100.5 \\
4 & 29.54 & 1.63 & 68.23 & 83.30 & 10.28 & 5.39 & 1.03 & 2021 & 103.3 \\
5 & 29.66 & 1.11 & 69.23 & 85.91 & 10.61 & 2.35 & 1.13 & 1424 & 72.8 \\
6 & 29.39 & 1.61 & 69.00 & 81.06 & 13.36 & 2.88 & 2.70 & 2100 & 107.4 \\
7 & 29.82 & 0.61 & 69.57 & 88.54 & 10.85 & 0.43 & 0.18 & 1891 & 96.7 \\
8 & 29.04 & 1.02 & 70.94 & 87.22 & 9.64 & 2.15 & 0.99 & 2069 & 105.8 \\
\hline
\end{tabular}

Parameter change made:

1: none

2: proportion of beef crossings $=0.00$

3: selection at stage $2=.40$

4 : net value of beef $=7.20$

5: discount rate $=.08$

6: genetic correlations

Milk
$\mathrm{M}_{\mathrm{c}}$
Beef
Milk
$\mathrm{M}_{\mathrm{c}}$
Beef

$\begin{array}{rrr}\mathrm{M}_{\mathrm{c}} & \text { Beef } & \mathrm{B}_{\mathrm{c}} \\ -.8 & .3 & -.6 \\ & -.6 & .7 \\ & & -.8 \\ -.6 & 0 . & .0 \\ & .0 & .0 \\ & & -.6\end{array}$

8: bull's own prog. test on $\mathrm{M}_{c}$ based on 5 daus. included into the selection index.

\section{Measuring feed consumption}

Measuring feed consumption on a beef performance test station increases the labour costs, but this cost $\left(1 \frac{1}{2}-3\right.$ persons per 100 bulls $)$ is very modest in comparison to the economic gains at the national level. The contribution of one percent improvement in feed conversion ratio to the overall economic gain in our population (455 000 animals slaughtered) is alone worth close to 10 mill. fmk ( $\$ 1.8$ mill.). So far one has relied on the high correlations (0.60.8 ) usually noted between growth rate and feed conversion. However, it should be realised that many of these are biased because of the part - whole relationship (SUTHERLAND 1965) and because no adjustments have been made for metabolic body size (BLUM 1976) and the higher adult maintenance costs. Therefore, direct measurement of feed conversion ratio might be more rewarding than it at first sight appears. Measurement of feed conversion on the test station becomes more important as the correlation between feed conversion in beef and milk production rises.

Feed conversion ratio contributes as a whole (beef + milk) over $10 \%$ to the total economic gain. As most of this gain comes from the milk side it seems advantageous to develop methods for measuring feed conversion in milk production. It is as yet impractical to measure feed consumption in all recorded herds. In principle we can think of 3 simpler methods of measuring 
feed consumption : (a) recording the consumption individually for selected bull dams, (b) setting up progeny test stations in Danish fashion and (c) measuring consumption in the field. We made some calculations on (a); they indicated that this method contributed below $1 \%$ to the overall economic gain. Alternative (b) in turn is cumbersome and relatively expensive to carry out. Therefore, alternative (c) seems the most promising one. If this testing is restricted to 5-10 daughters per young bull we would in Finland need to measure the feed consumption of only $600-1200$ recorded cows. This does not seem impossible to carry out in practice. According to HOOVEN et al. (1972), the genetic correlation of feed conversion efficiency 121-150 days after calving and the feed conversion efficiency of the whole lactation is high, close to unity. The heritability of feed efficiency 121-150 days after calving was $0.44 \pm .07$. Thus a one month recording period, carried out by the farmers themselves, supervised once or twice by milk recorders, might give sufficiently accurate results for progeny testing bulls. Another possibility is measuring feed consumption individually for 100-200 daughters per selected young bulls in mid-lactation only once or twice - in connection with the milk recorders visit to the farm. Even if these testing procedures would increase the overall testing costs, the additional benefits would clearly outweigh the expenditures.

\section{References}

BECH-ANDERSEN, B. B. 1977. Genetiske undersøgelser vedrørende kvaegets tilvaekst, kropsudvikling og foderudnyttelse. (Genetic investigations of growth, body development and feed utilization in dual purpose cattle) 448. Beretning fra Statens Husdyrbrugs forsøg, Denmark, 137 p.

BLUM, J. K. 1976. Selection for feed conversion: direct and correlated responses and genetic parameters. Thesis, Kansas State Univ., Manhattan, Kansas, 38 p.

BOA (Board of Agriculture) 1982. Statistics of the activity of milk recording societies in Finland 1980/81, no 386. Helsinki.

CUNNINGHAM, E. P. 1975. Multistage index selection. Theor. Appl. Gen. 46: 55-61.

- \& McCLINTOCK, A. E. 1974. Selection in dual purpose cattle populations: effects of beef crossing and cow replacement rates. Ann. Génét. Sél. Anim. 6(2): 227-239.

DICKINSON, F. N., McDANIEL, B. T. \& McDOWELL, R. E. 1969. Comparative efficiency of feed utilization during first lactation of Ayrshire, Brown Swiss and Holstein cows. J. Dairy Sci. 52: 489-497.

FREEMAN, A. E. 1967. Genetic aspects of the efficiency of nutrient utilization for milk production. J. Anim. Sci. 26: 976-983.

FRIEDEL, R. \& RYBKA, P. 1980. Populationsgenetische Untersuchungen zur Schätzung der Beziehungen zwischen Milchleistung und Wachstum beim Rind. Arch. Tierzucht 23: 31-40.

HOOWEN; N. W., MILLER, R. H. \& PLOWMAN, R. D. 1968. Genetic and environmental relationship among efficiency, yield, consumption and weight of Holstein cows. J. Dairy Sci. 51: 1409-1419.

— , MILLER, R. H., Jr. \& SMITH, J. W. 1972. Relationships among whole - and part - lactation gross feed efficiency, feed concumption, and milk yield. J. Dairy Sci. 55: 1113-1122.

LINDSTRÖM, U. B. 1974. Points of view of performance testing dual purpose bulls. Z. Tierzüchtg. Züchtungs biol. 91: 11-21.

- \& VILVA, V. 1977. Economic breeding for milk and beef in the Finnish Ayrshire. Symp. Ay-cattle, 1976, Finland. Proc.: 140-159. 
McCLINTOCK, A. E. \& CUNNINGHAM, E. P. 1974. Selection in dual purpose cattle populations: defining the breeding objective. Anim. Prod. 18: 237-247.

SKJERVOLD, H. 1967. Selection schemes in relation to artificial insemination. Rep. of Proc. and Inv. papers. 9th Int. Congr. Anim. Prod. (1966): 250-261.

- 1977. Framtidsperspektiver i fenotype testingen av potensielle seminokser (Future aspects on performance testing of potential AI bulls). Nordic symp., Helsinki 14. 9. 1977, Mimeo 26 p.

SMITH, C. 1978. The effect of inflation and form of investment on the estimated value of genetic improvement in farm livestock. Anim. Prod., 26: 101-110.

SURHERLAND, T.M. 1965. The correlation between feed efficiency and rate of gain, a ratio and its denominator. Biometrics 21: 739-749.

Ms received December 14, 1983

SELOSTUS

\title{
Maito-lihaohjelma - kokonaisstrategian suunnittelu
}

\author{
Veijo Vilva \& U. B. Lindström
}

\section{Helsingin yliopiston kotieläinten jalostustieteen laitos, 00710 Helsinki 71}

Kolmivaiheista maito-lihasonnien valintaohjelmaa tutkittiin valintavaiheiden merkityksen ja odotettavissa olevan geneettisen edistymisen selvittämiseksi. Aikaisempien tutkimusten tavoin tulokset osoittivat, että yli $90 \%$ taloudellisesta edistymisestä tulee maito-ominaisuuksista. Lisäksi tutkimus osoitti, että yli $10 \%$ edistymisestä johtuu parantuneesta rehuhyötysuhteesta lähinnä maidontuotannossa. Nuorten sonnien fenotyyppitesti vastasi vain 1-2 \% kokonaisedistymisestä. Tämän vuoksi kasvatusasemia voitaisiin käyttää tehokkaammin keskittymällä rehunkäyttökyvyn mittaamiseen. Tutkimus osoitti myös, että suora valinta maidontuotannon rehuhyötysuhteen suhteen antaisi selvästi nopeamman edistymisen, vaikka se perustuisi vain 5 tyttäreen sonnia kohden. Käytännössä tämä voitaisiin suorittaa mittaamalla kunkin nuoren sonnin osalta pienen tytärjoukon rehunkulutus 4-5 kuukautta poikimisen jälkeen noin kuukauden ajan tai keräämällä nuorten sonnien tyttäriltä 200-300 yksittäistä rehunkulutustietoa laktaatiokauden keskivaiheilta. 